\title{
Pensonomonoor
}

2015, vol. 74, 109-122

http://dx.doi.org/10.12657/denbio.074.011

\author{
Anna K. Jasińska, Beata Rucińska, Gregor Kozlowski, \\ Sébastien Bétrisey, Hajiaga Safarov, Krystyna Boratyńska, \\ Adam Boratyński
}

\section{Morphological differentiation of leaves in the relict tree Zelkova carpinifolia (Ulmaceae)}

Received: 15 December 2014; Accepted: 16 March 2015

\begin{abstract}
Zelkova carpinifolia is a relict tree occurring in refugial zones of south-western Eurasia. The main aim of the study was the biometrical comparison of the leaf characteristics of the species sampled in three regions of Transcaucasia. We aimed to test the hypotheses that (1) leaves from vegetative (L) shoots would be larger and more variable than those from fertile (S) shoots, (2) the leaves from the same shoot type express geographic patterns of morphological differentiation, similar to pattern described for genetic markers and (3) to verify the systematic position of $Z$. hyrcana and $Z$. carpinifolia subsp. yomraensis. The plant material was collected from 5 populations of $Z$. carpinifolia, one of $Z$. hyrcana and one of $Z$. carpinifolia subsp. yomraensis. The total 1482 leaves, 713 from L- and 769 S-type were measured using 26 characters. Our results show very high level of differences between leaves from the L- and S-type of shoots. The majority of leaf characters did not reveal dependence neither on geographic latitude, longitude and altitude nor on the basic climatic data. The results of multivariate analyses of $S$ leaves revealed three group of populations, namely from (1) Colchis, (2) eastern Caucasus (3) Talysh. Thus, our biometric analyses revealed similar pattern to the haplotypic differentiation of $Z$. carpinifolia detected using chloroplast markers described in the literature. We did not detected significant differences in the leaf characters between supposed $Z$. hyrcana and/or Z. carpinifolia subsp. yomraensis, when compared to Z. carpinifolia, thus not confirming their separate taxonomic status.
\end{abstract}

Additional key words: biogeography, biometry, leaf morphology, plant variation, taxonomy, Talysh, Transcaucasia

Addresses: A.K. Jasińska, K. Boratyńska, A. Boratyński, Polish Academy of Sciences, Institute of Dendrology, Parkowa 5, 62-035 Kórnik, Poland, e-mail: borata@man.poznan.pl

B. Rucińska, Kazimierz the Great University, Department of Botany, al. Ossolińskich 12, 85-093

Bydgoszcz, Poland

G. Kozlowski, S. Bétrisey, Department of Biology and Botanic Garden, University of Fribourg, Chemin du Musée 10, CH-1700 Fribourg, Switzerland

G. Kozlowski, S. Bétrisey, Natural History Museum Fribourg, Chemin du Musée 6, CH-1700 Fribourg, Switzerland

H. Safarov, Institute of Botany, Azerbaijan National Academy of Sciences, Batamdar shosse 40, AZ1073 Baku, Azerbaijan

H. Safarov, Hirkan National Park, AZ4235 Lankaran, Azerbaijan 


\section{Introduction}

Species of the genus Zelkova (Ulmaceae) were important elements of the vast forests that prevailed throughout the Northern Hemisphere during much of the Cenozoic Period (Mai 1995). Today, this genus comprises six extant species with disjunct distribution patterns (Denk and Grimm 2005). Three species occur in eastern Asia: Z. serrata (Thunb.) Makino, Z. schneideriana Hand.-Mazz. and Z. sinica C. K. Schneid. In western Eurasia, the genus is represented by Z. carpinifolia (Pall.) C. Koch and two species on the Mediterranean islands of Sicily (Zelkova sicula Di Pasq., Garfi \& Quézel) and Crete [Zelkova abelicea (Lam.) Boiss.] (Kozlowski and Gratzfeld 2013). The oldest fossils that are attributed to Zelkova date from the early Eocene (55 Ma) in western North America, where the genus is extinct (Burnham 1986).

Zelkova carpinifolia is one of the most iconic relict trees in Transcaucasia (Kozlowski and Gratzfeld 2013). This species grows in Georgia, Armenia, Azerbaijan, Iran and Turkey (Güner and Zielinski 1998) and is a large tree, attaining an average height of 2035 (40) $\mathrm{m}$ and measuring up to $2 \mathrm{~m}$ in diameter. This species is a typical element of the humid broadleaved forests of Colchis as well as those of the Elburz and Talysh Mountains along the southern Caspian shore, generally from the lowland up to an altitude of approximately 1500-1550 m (Prilipko 1961; Zieliński 1979; Browicz and Zieliński 1982a,b; Kozlowski and Gratzfeld 2013). The Transcaucasian area is considered one of the most important refugial zones of the Cenozoic relict flora in south-western Eurasia (Mai 1995; Milne and Abbott 2002). The ancient range of $Z$. carpinifolia was most likely much broader, mostly during late Neogene and early Quaternary periods (Manchester 1989; Mai 1995; Denk and Grimm 2005). The most frequently cited data are documented by fossil leaves, which are generally variable and attributed to the fossil Z. zelkovifolia (Ung.) Bùžek et Kotl. The fossil leaves in the same deposits frequently present morphotypes that are very similar to those of the leaves of modern $Z$. carpinifolia or east Asiatic Z. serrata (Mai 1995; Denk and Grimm 2005) and in Europe also to Z. sicula and Z. abelicea (Hably 1997; Hably and Kvaček 1998; Denk and Grimm 2005).

The Zelkova leaf shape, size, venation and type of serration are variable and only partly characteristic for particular species, as was found in the phylogenetic analysis of the contemporary species (Denk and Grimm 2005). The leaf character of particular species depends on the type of the sprout from which leaves originate. The leaves from the sucker shoots (SS) are the largest, while those from the vegetative shoots (L) are somewhat smaller, and both types are different from the leaves of fruiting shoots (S) (Lozina-Lozinskaya 1951; Wang et al. 2001; Denk and
Grimm 2005). The latter are smaller, more regularly serrated and believed to be not as variable as $\mathrm{L}$ and SS leaves.

The leaves of dicotyledonous trees are generally recognized as being strongly influenced by environmental conditions (Kovačić and Nikolić 2005; Xu et al. 2009; Marcysiak 2012a,b,c), with a dimension and shape that are dependent to some degree on the posi-
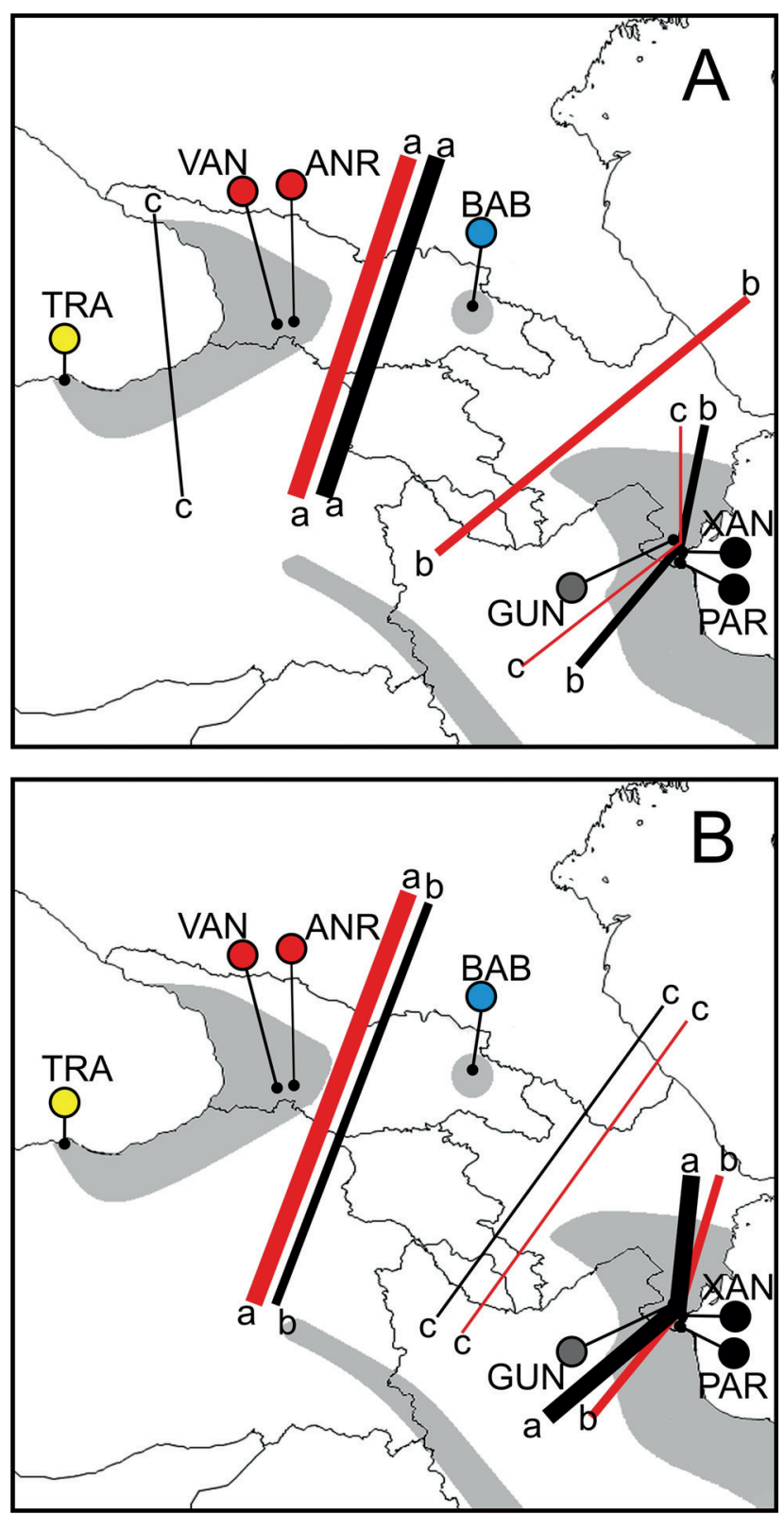

Fig. 1. Geographic range of Zelkova carpinifolia (after Browicz and Zieliński 1982b, simplified) and sampled population positions (acronyms as in Table 1) with barriers $(\mathrm{a}, \mathrm{b}$, and $\mathrm{c})$ that were detected using Barrier: $\mathrm{A}$ - on Euclidean distances between populations and B - on Mahalanobis distances between populations; red lines indicate significant distances on data from L-type shoot, while black indicate data from S-type shoot; and the thickness of the lines indicates the importance of the barrier: the thickest lines (a) are the most important, while the thinnest (c) are the least important 
tion on the shoot (e.g., Mejnartowicz 1972; Wójcicki 1997; Wang et al. 2001). Additionally, leaves can be strongly modified as an effect of animal impact on the trees (e.g., Boratyński et al. 1987).

According to phylogenies that were constructed on the leaf morphology and ITS variation, Z. carpinifolia forms a different clade, while European Z. abelicea and $Z$. sicula are more similar to $Z$. serrata (Denk and Grimm 2005). This distinct position of $Z$. carpinifolia within the genus, its relic geographic range and historical demography (Christe et al. 2014) are most likely responsible for the high level of the species morphological variation that accumulated in the separate regions, which resulted among other effects in the description of $Z$. hyrcana Grossh. et Jarm. from the Talysh in southern Azerbaijan (Prilipko 1961) and Z. carpinifolia subsp. yomraensis from Trabzon vicinity in Turkey (Anşin and Gerçek 1991). The latter was verified as the juvenile state of $Z$. carpinifolia (Zieliński and Güner 2000) but without an anatomical analysis of the wood. Zelkova hyrcana is characterized by leaves from vegetative shoots that are $2-3.5 \mathrm{~cm}$ long and with 6-7 veins, while $Z$. carpinifolia leaves are 4-6 $\mathrm{cm}$ long with 7-9 veins (Prilipko 1961). The taxonomic value of $Z$. hyrcana, however, have not been confirmed (e.g., Safarov 1967; Browicz and Zieliński 1972a,b; Zieliński 1979; Wang et al. 2001; Kozlowski et al. 2012; Christe et al. 2014), albeit that the name Z. hyrcana is still in consideration (Aliyev 1995; Uotila 2011). The results of molecular analyses also did not support the taxonomic distinctiveness of $Z$. carpinifolia subsp. yomraensis (Christe et al. 2014).

Following the principles of leaf variation that were mentioned above, we hypothesize that (a) leaves from L-type shoots will be larger and more variable than those from S-type shoots, (b) the leaves from the same type of the shoot and the same position on the shoot may show some geographic patterns of morphological variation and/or dependence on the environmental conditions, and (c) the leaves of populations from Talysh (Z. hyrcana) and vicinities of Trabzon (Z. carpinifolia subsp. yomraensis) do not differ from leaves of other populations, representing typical Z. carpinifolia. Consequently, the aim of the study was the biometrical comparison of the leaf ma- terial that was sampled in various regions from the two types of the shoots (L and S) and the verification of the above hypotheses. We expected that our data would provide precise comparative material for future palaeobotanical studies.

\section{Material and Methods}

\section{Plant material}

The plant material was collected from seven populations, among them five of $Z$. carpinifolia subsp. carpinifolia, one of $Z$. hyrcana and one of $Z$. carpinifolia subsp. yomraensis (Fig. 1, Table 1). The fully developed, not damaged leaves from the central parts of the shoot types $\mathrm{L}$ and $\mathrm{S}$ were gathered from the south-facing parts of the tree crowns 1.5-3 m above the ground level. The leaves were pressed and dried as herbarium materials and preserved in this state for the biometrical analyses. The material was used to estimate the differences between leaves from L-type and S-types of shoots and the diversity and differentiation of the species and to validate the systematic position of $Z$. hyrcana and $Z$. carpinifolia subsp. yomraensis compared to that of $Z$. carpinifolia s. str. Every individual within a population was characterized using (7-) 10 leaves from L- and/or S-type shoots. The total 1482 leaves, 713 from L-type and 769 from S-type shoots, were measured. The differences between the numbers of tested leaves that were collected from L-type and S-types of shoots resulted from lack of L-type leaves in population TRA, where only fructifying shoots were sampled (Table 1).

\section{Measurement procedures}

Every leaf was characterized using 26 features: 17 measured and/or counted and another 9 resulting from recalculations (Table 2). Additionally, the types of leaf bases (S_1-S_11) were estimated (Fig. 2). The leaf character set was adopted following results of the studies of the leaves of Carpinus, Corylus, Quercus, Salix and Alnus (Białobrzeska 1970a,b; Kremer et al. 2002). The leaves were measured using color pic-

Table 1. Sampled populations of Zelkova carpinifolia (including Z. hyrcana and Z, carpinifolia subsp. yomraensis); L - vegetative shoot, S - fertile shoot; N - number of individuals; AMT - Annual Mean Temperature, APR - Annual Precipitation

\begin{tabular}{|c|c|c|c|c|c|c|c|c|}
\hline Locality & Code & $\mathrm{N}$ & Leaf type & Longitude $\left[{ }^{\circ}\right]$ & Latitude $\left[{ }^{\circ}\right]$ & Altitude [m] & $\mathrm{AMT}\left[{ }^{\circ} \mathrm{C}\right]$ & APR $[\mathrm{mm}]$ \\
\hline $\begin{array}{l}\text { Turkey, Trabzon (Z. carpinifolia subsp. } \\
\text { yomraensis) }\end{array}$ & TRA & 7 & $S$ & 39.866 & 40.950 & 76 & 14.46 & 981 \\
\hline Georgia, Ajametis Nature Reserve & ANR & 20 & $\mathrm{~L}, \mathrm{~S}$ & 42.763 & 42.143 & 150 & 13.59 & 1303 \\
\hline Georgia, Vani & VAN & 16 & $\mathrm{~L}, \mathrm{~S}$ & 42.565 & 42.089 & 100 & 14.40 & 1402 \\
\hline Georgia, Babaneuri Nature Reserve & $\mathrm{BAB}$ & 17 & $\mathrm{~L}, \mathrm{~S}$ & 45.371 & 42.081 & 470 & 12.50 & 696 \\
\hline Azerbaijan, Xabulan & $\mathrm{XAN}$ & 10 & $\mathrm{~L}, \mathrm{~S}$ & 48.800 & 38.661 & 40 & 14.22 & 1086 \\
\hline Azerbaijan, Parakand & PAR & 10 & $\mathrm{~L}, \mathrm{~S}$ & 48.803 & 38.650 & 40 & 14.22 & 1086 \\
\hline Azerbaijan, Güneshli (Z. hyrcana) & GUN & 10 & $\mathrm{~L}, \mathrm{~S}$ & 48.469 & 38.805 & 650 & 12.58 & 612 \\
\hline
\end{tabular}


Table 2. Average values of leaf characters of Zelkova carpinifolia; L - vegetative shoots, $\mathrm{S}$ - fructifying shoots, $\mathrm{M}$ - arithmetic mean, Min - minimum, Max - maximum, V - variation coefficient, $\mathrm{p}$ - significance of results of Student's $t$-test

\begin{tabular}{|c|c|c|c|c|c|c|c|c|c|c|}
\hline \multirow{2}{*}{ Leaf character } & \multirow{2}{*}{$\begin{array}{c}\text { Acro- } \\
\text { nym }\end{array}$} & \multicolumn{4}{|c|}{$\mathrm{L}$} & \multicolumn{4}{|c|}{$\mathrm{S}$} & \multirow{2}{*}{$\begin{array}{l}\text { Student } \\
\text { test } \mathrm{p}\end{array}$} \\
\hline & & M & Min & Max & $\mathrm{V}$ & M & Min & Max & $\mathrm{V}$ & \\
\hline Leaf blade surface $\left(\mathrm{cm}^{2}\right)$ & A & 12.28 & 3.21 & 37.90 & 35.02 & 4.37 & 1.15 & 11.61 & 37.27 & $<0.0001$ \\
\hline Leaf blade circumference $(\mathrm{cm})$ & $\mathrm{P}$ & 19.59 & 9.70 & 36.73 & 20.66 & 11.21 & 3.96 & 21.38 & 24.68 & $<0.0001$ \\
\hline Leaf blade length $(\mathrm{cm})$ & $\mathrm{BL}$ & 5.83 & 2.54 & 10.62 & 16.06 & 3.43 & 1.13 & 6.26 & 21.72 & $<0.0001$ \\
\hline Leaf blade maximum width $(\mathrm{cm})$ & BW & 2.97 & 1.44 & 5.53 & 20.35 & 1.82 & 0.59 & 2.92 & 18.26 & $<0.0001$ \\
\hline Leaf blade width in $50 \%$ of length $(\mathrm{cm})$ & BW_50 & 2.78 & 1.31 & 5.28 & 20.28 & 1.68 & 0.48 & 2.79 & 19.14 & $<0.0001$ \\
\hline Leaf blade width in $90 \%$ of length $(\mathrm{cm})$ & BW_90 & 0.77 & 0.26 & 2.30 & 27.64 & 0.51 & 0.15 & 1.19 & 25.92 & $<0.0001$ \\
\hline $\begin{array}{l}\text { Distance between midrib and denticle apex at maxi- } \\
\text { mal width of leaf blade. along the lateral vein }(\mathrm{cm})\end{array}$ & LLV & 2.29 & 1.05 & 4.33 & 19.15 & 1.31 & 0.34 & 2.30 & 24.13 & $<0.0001$ \\
\hline $\begin{array}{l}\text { Distance between midrib and denticle apex below } \\
\text { maximal width of leaf. along the lateral vein }(\mathrm{cm})\end{array}$ & LV & 2.13 & 1.01 & 4.07 & 19.56 & 1.21 & 0.35 & 2.26 & 24.58 & $<0.0001$ \\
\hline $\begin{array}{l}\text { Distance between midrib and indentation between } \\
\text { LLV and LV }(\mathrm{cm})\end{array}$ & LI & 1.85 & 0.88 & 3.65 & 18.99 & 1.04 & 0.33 & 1.89 & 23.19 & $<0.0001$ \\
\hline Distance from basis to maximal width of leaf $(\mathrm{cm})$ & LWP & 2.64 & 0.92 & 5.48 & 21.15 & 1.43 & 0.09 & 3.04 & 31.58 & $<0.0001$ \\
\hline Angle of leaf blade apex $\left(^{\circ}\right)$ & AA & 38.59 & 13.21 & 98.73 & 16.10 & 42.97 & 18.19 & 88.15 & 19.07 & 0.0001 \\
\hline Angle of leaf blade basis $\left(^{\circ}\right)$ & $\mathrm{AB}$ & 99.34 & 48.92 & 168.63 & 9.75 & 99.92 & 49.33 & 160.55 & 11.20 & 0.7171 \\
\hline Number of leaf denticles on one side of leaf blade & $\mathrm{TN}$ & 10.19 & 6 & 16 & 11.19 & 8.84 & 5 & 15 & 14.81 & $<0.0001$ \\
\hline Number of lateral veins of one side of leaf blade & NVT & 9.45 & 5 & 15 & 11.66 & 8.19 & 4 & 15 & 15.24 & $<0.0001$ \\
\hline Length of longer side of blade $(\mathrm{cm})$ & LHL & 5.79 & 2.62 & 10.58 & 16.84 & 3.48 & 1.18 & 7.60 & 22.28 & $<0.0001$ \\
\hline Length of shorter side of blade $(\mathrm{cm})$ & SHL & 5.98 & 2.83 & 10.82 & 16.97 & 3.55 & 1.19 & 7.88 & 22.22 & $<0.0001$ \\
\hline Asymmetry of leaf blade [100× (LHL-SHL/LHL)] & LA & 3.06 & 0.00 & 12.67 & 65.28 & 2.03 & 0.00 & 10.31 & 63.55 & $<0.0001$ \\
\hline $\begin{array}{l}\text { Ratio of the number of nerves to the number of teeth } \\
{[100 \times(\mathrm{NVT} / \mathrm{TN})]}\end{array}$ & PV & 92.86 & 66.67 & 100.00 & 4.05 & 92.80 & 44.44 & 120.00 & 3.97 & 0.9191 \\
\hline $\begin{array}{l}\text { Leaf blade width in } 90 \% / \text { maximum width } \\
{[100 \times(\text { BW_90/BW })]}\end{array}$ & W_1 & 26.09 & 14.12 & 71.09 & 15.77 & 27.89 & 13.91 & 58.04 & 14.58 & 0.0042 \\
\hline $\begin{array}{l}\text { Leaf blade width in } 50 \% / \text { maximum width } \\
{[100 \times(\mathrm{BW} 550 / \mathrm{BW})]}\end{array}$ & W_2 & 93.82 & 78.68 & 100.00 & 2.57 & 92.11 & 65.70 & 100.00 & 3.38 & 0.0001 \\
\hline $\begin{array}{l}\text { Leaf blade width in } 90 \% \text { / width in } 50 \% \text { of length } \\
{[100 \times(\text { BW_90/BW_50)] }}\end{array}$ & W_3 & 27.82 & 14.87 & 74.18 & 15.52 & 30.25 & 14.68 & 63.36 & 13.32 & 0.0002 \\
\hline Leaf blade surface to circumference ratio (A/P) & AP & 0.60 & 0.33 & 1.05 & 16.86 & 0.38 & 0.14 & 0.63 & 14.94 & $<0.0001$ \\
\hline Position of leaf maximal width $[100 \times(\mathrm{LWP} / \mathrm{BL})]$ & LBW & 44.97 & 23.44 & 67.26 & 10.73 & 40.84 & 4.15 & 60.06 & 14.55 & $<0.0001$ \\
\hline Serration depth $[(\mathrm{LLV}+\mathrm{LV}) / 2-\mathrm{LI}]$ & DI & 0.36 & 0.14 & 0.73 & 25.17 & 0.22 & 0.04 & 0.53 & 32.08 & $<0.0001$ \\
\hline Leaf blade length/width (BL/BW) & LS & 2.00 & 1.08 & 3.09 & 12.47 & 1.89 & 1.12 & 2.99 & 12.64 & 0.0047 \\
\hline
\end{tabular}

tures of 300-dpi resolution of the underside (abaxial side) of a dry leaf that were obtained from the scanner Epson V700 using WinFolia Pro2003 (Regent Instruments Inc.) software. The characters $\mathrm{A}, \mathrm{P}, \mathrm{BL}$, BW, BW_50, BW_90, LLV, LV, LI, LWP, AA and AB were measured automatically, while TN, NVT, SHL, LHL and S_1-S_11 were counted, assumed or measured manually in WinFolia (Table 2).
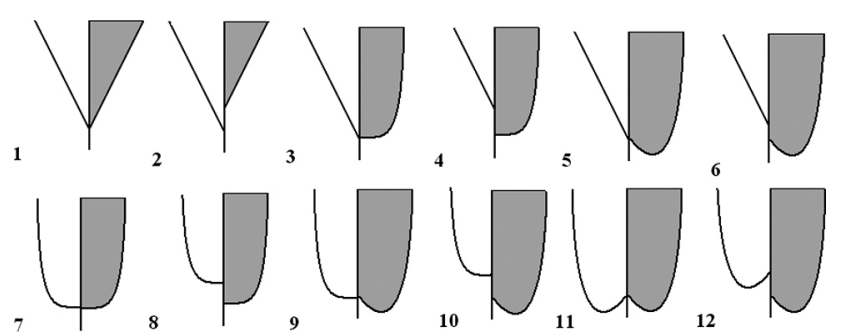

Fig. 2. Shape of leaf blade bases of Zelkova carpinifolia

\section{Statistical analyses}

The frequency distribution of measured and estimated leaf character values was verified using the Shapiro-Wilks tests and frequency histograms to assess the data symmetry and unimodality. The skewed data for particular characters were transformed to obtain their unimodal and normal distribution (Zar 1999; Sokal and Rohlf 2003). The homoscedasticity of the data variances was verified by Brown-Forsythe's test to assess the possibility of using parametric statistical tests (Sokal and Rohlf 2003). The data were standardized before further analyses according to STATISTICA 10 (StatSoft) procedures.

The arithmetic mean (M), standard deviation (D) and variation coefficient $(\mathrm{V})$ were calculated for every leaf type and separately for every population to determine the range of diversity. The possible interaction between pairs of characters was determined 
using Pearson's correlation coefficient to avoid possible redundant variables (Zar 1999). The level of statistical significance of the differences between the mathematic mean values of particular characters between populations was verified using Tukey's post hoc Honest Significant Differences T-test and $t$-test for independent samples by groups (Zar 1999; Sokal and Rohlf 2003). The same test was used to detect the level of differences between $Z$. carpinifolia subsp. carpinifolia, Z. carpinifolia subsp. yomraensis and Z. hyrcana, the two later taxa being represented by single populations (Table 1).

The possible dependence of values of particular leaf characters on longitude, latitude and altitude and the Annual Mean Temperature (AMT) and Annual Precipitation (AP) were verified using the Spearman's coefficient $r_{s}$ (Sokal and Rohlf 2003). Meteorological data were retrieved from the DIVA-GIS database. The JMP (SAS Institute, Inc.) was used in the calculations.

The relationships among the populations and the level of population differentiation independent of taxonomic status were evaluated using a principal components analysis (PCA) and Fisher discrimination function analysis (FDA), followed by agglomeration after Ward's method on the Euclidean and Mahalanobis' distances. The recalculated characters (LA, PV, W 1, W 2, AP, LBW, DI, LS), the simple not included within the recalculated characters (AA, AB, Table 2) and arcsined values of characters $S$ 1-S 11 were used in these analyses. The W 3 was excluded because of a very high correlation with W 2 (see below). The data were standardized before the analyses to avoid the possible influence of variation resulting from the different types of characteristics that were investigated (Sokal and Rohlf 2003; Stanisz 2007a,b). The STATISTICA software (StatSoft) was used in the analyses.

To evaluate the relationship between the geographical and morphological multi-character differences among the populations, a Mantel test (Mantel 1967) was performed on the matrices of Euclidean and Mahalanobis distances and the geographical distances between populations using the PopTools v. 3.2.5 software program. The geographical distances between the populations were determined in terms of coordinates using the MapInfo Professional 10.5 PL software (Pitney Bowes). The main barriers between populations were analyzed based on geographical and Mahalanobis distances using Barrier 2.2 (Manni et al. 2004).

\section{Results}

\section{Variation and correlation of characters}

Most of the examined characters of $Z$. carpinifolia leaves from L- and/or S-type of hoots showed un- imodal and normal or nearly normal distributions in every compared population. The Shapiro-Wilks' test detected a not-normal distribution of data for L shoots in the character BW_90 in 4 populations; LA, LS and LBW in two populations; and AP, AB, BW, SHL, LHL, A, P, AA and PV in one population each. The AB, LA, LS and DI were transformed using decimal logarithms, and S_1-S_11 was arcsined before analyses. The not-normal distribution for leaves from $S$ shoots was detected in the data of LS and TN in three populations; LBW and NVT in two; and in AA, SHL, LHL, LA, AB, PV and W_1 in one population each. The GUN population had every character with a normal distribution. Similar to the case of the leaves from the $\mathrm{L}$ shoots, the skewed characters were logarithm-transformed, and the percentage data from S 1-S 11 were arcsined before analyses.

The data variations for the $\mathrm{L}$ shoot leaves were homoscedastic, while 9 of those for the S shoot revealed a significant level of variance heterogeneity in Brown-Forsythe's test (characters LS, W_2, AB, S_4, S_6, S_8, S_10 and LBW with $\mathrm{p} \leq 0.01$ and $\mathrm{DI} \leq 0.0 \overline{5}$ ). The latter were more homogenic after standardization. The unimodality, normal distribution and homoscedasticity of the data after transformation and standardization enable the application of multivariate analyses and an analysis of variance.

The most variable characters in the leaves from both types of shoots were LA and A, at approximately 65 and more than 35\%, respectively. The most stable characters were $\mathrm{W} 22$ and PV, at approximately 3 and $4 \%$, respectively (Table 2 ).

The characters of both types of leaves (L and S) describing size of the leaf blade correlated positively at a high level. The highest correlation for the leaves from the L-type shoots was detected between the characters LLV, LV and LI $(r=0.99$ in every possible combination) and then between BW and BW_50 $(r=0.99)$. The same characters correlated in the leaves from the S-type shoots: LLV and LV $(r=1)$, and LI and LLV and LV ( $\mathrm{r}=0.99$ in both cases), and between BW and BW_50 $(r=0.99)$. Among the recalculated characters, the highest correlation was found between W_1 and W_3 ( $\mathrm{r}=0.99$ and $\mathrm{r}=0.98$ for leaves from $\bar{L}$-type and $\bar{S}$-type shoot, respectively).

Finally, only the recalculated characters and AA, $A B$ and $S$ 1-S 11, which were not included in the recalculated characters, were used in the multivariate analyses in both types of datasets.

\section{Differences between the leaves from the L- and S-type of shoots}

The leaves from the S-type of shoots were generally smaller than were those from the L-type but with a broader angle of the leaf blade apex (AA) (Table 2). The leaves of the L (713 leaves) and S (769 leaves)- 
type shoots were compared using the $t$-test. All of the characters except for $\mathrm{AB}$ and $\mathrm{PV}$ showed significant differences $(p \leq 0.05)$. The PCA confirmed high level of differences between the leaves from the L-type and
S-type shoots (Fig. 3A). A similar result was detected using a discrimination analysis (Fig. 3B) and an agglomeration of the closest Euclidean distances (Fig. 3C) and Mahalanobis distances (data not shown).

A

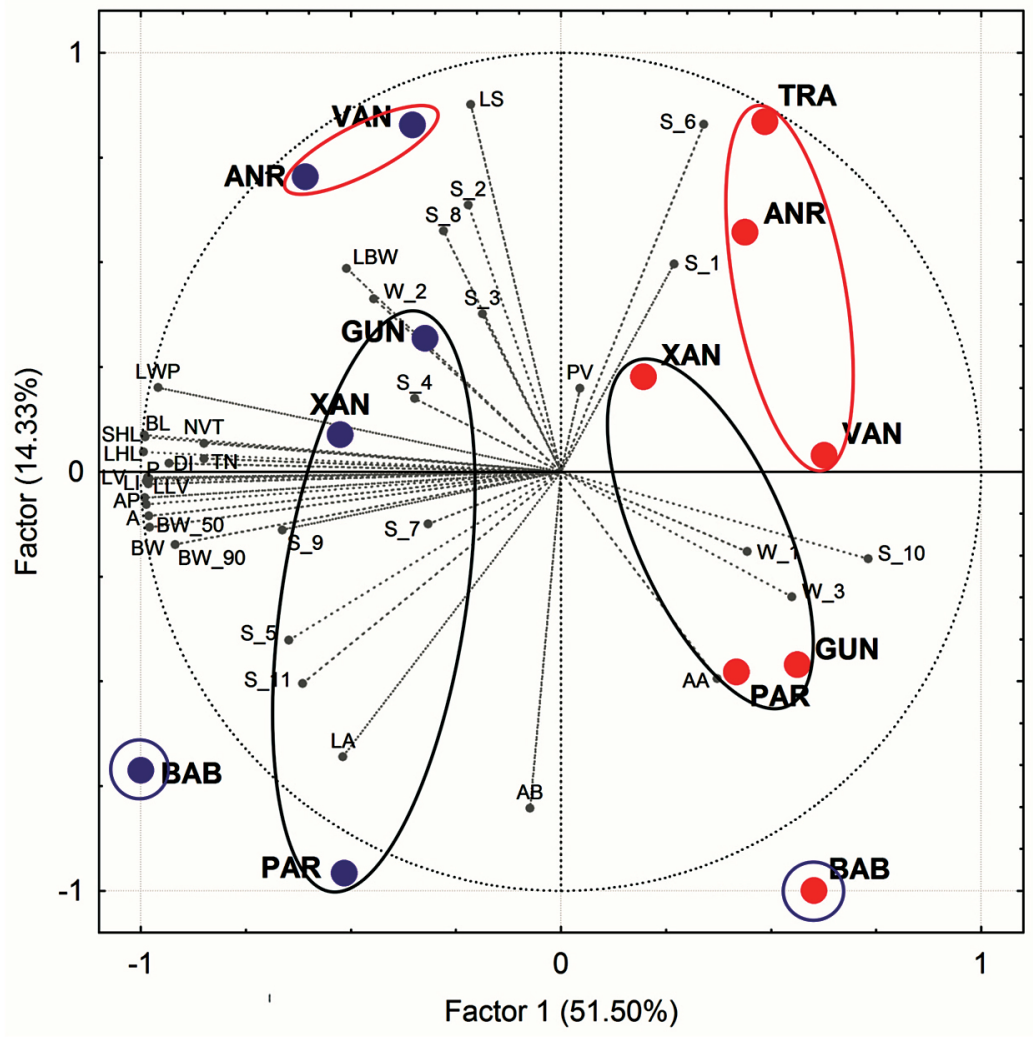

B

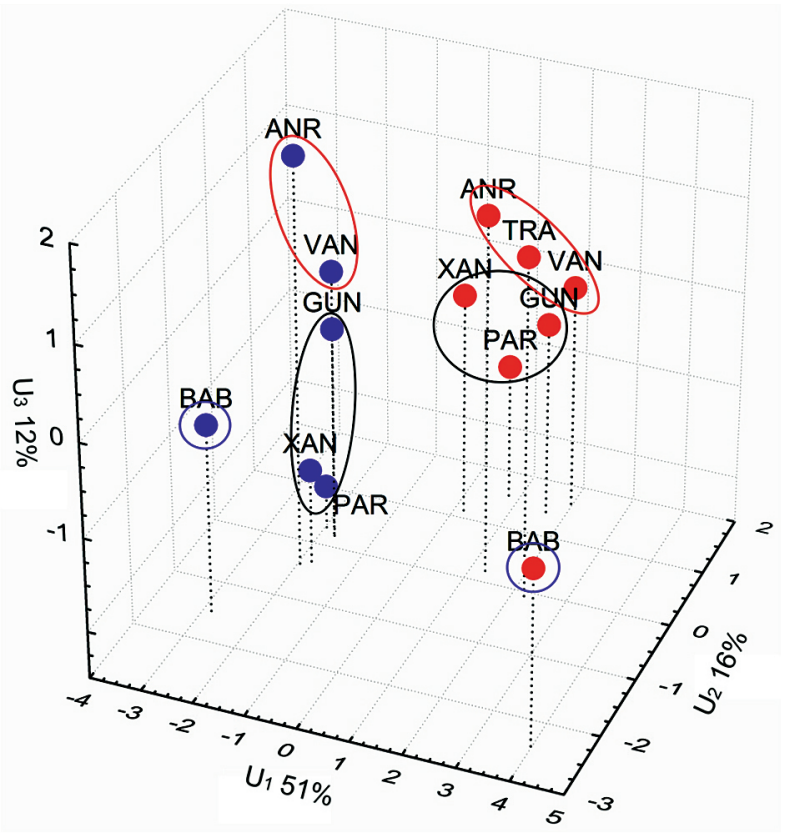

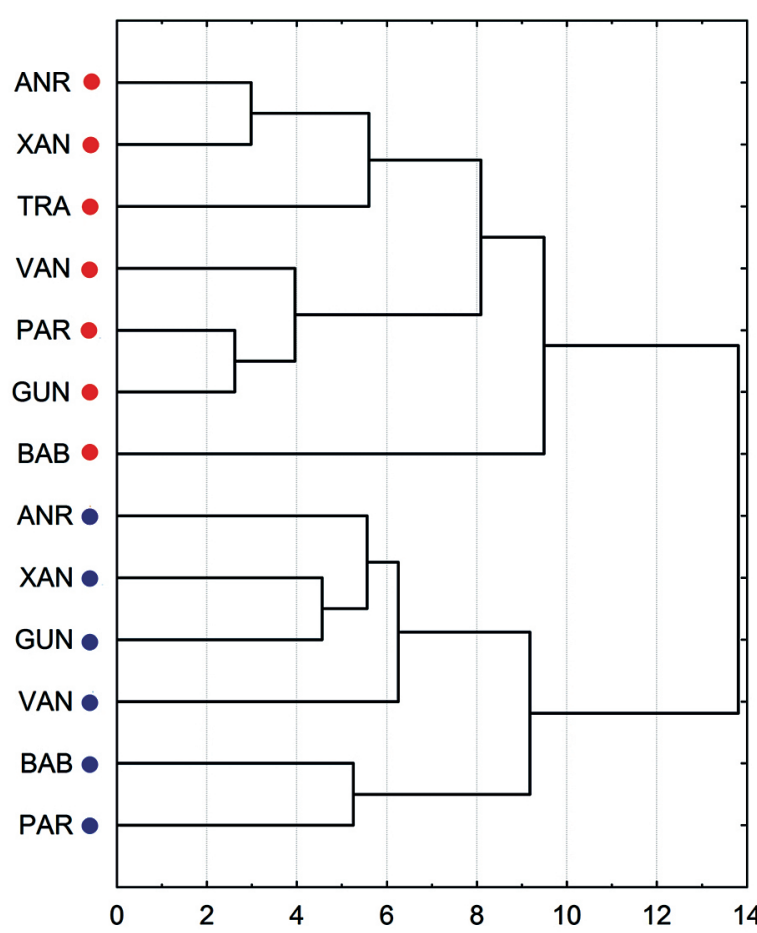

Fig. 3 Differentiation of populations of Zelkova carpinifolia (acronyms as in Table 1) based on: • - L-type shoot, • - S-type shoot. A - PCA (character codes as in Table 2), B - analysis of discrimination, and C - agglomeration on the Euclidean distances 
Every analysis differentiated populations first by all of the leaves of $L$ versus those of $S$ and then between populations in these two groups.

The PCA indicated that the characters BL, SHL, LHL, LV, LLV, LI, A, AP and LWP as describing the leaves from the L- versus S-type of shoots with the highest power and detected a rather slight influence on the differentiation types of the leaf basis. From the latter, only S_6 had a greater impact to the differentiation of populations on the PCA scatter plot. The first-mentioned character set influenced mostly the first PCA factor, while the remaining characters influenced both of the factors.

The dispersion of the studied populations among the 3 first discrimination variables $U_{1}, U_{2}$ and $U_{3}$, which were responsible for $79 \%$ of the total variation, revealed the differences resulting from the origin of leaves from L- versus S-type shoots (Fig. 3B). These differences were detected by the first discriminating variable $\mathrm{U}_{1}$, which was determined mostly by the characters AP, DI and S_10.

\section{Position and climate influence on the leaf characteristics}

The leaf characters that were used in the analyses generally did not reveal dependence on the geographic position of the populations. Only the proportion of the leaf blade in its middle to maximal width (W_2) in the leaves from the S-type shoots correlated positively with the geographic latitude and negatively with the longitude $\left(r^{2}=0.897, p=0.004\right.$ and $r^{2}=0.686, p=0.042$, respectively). Among all of the characters, only the angle of the leaf blade $(A B)$ of leaves from S-type shoots correlated negatively with the AMT and APR $\left(\mathrm{r}^{2}=0.651, \mathrm{p}=0.052\right.$ and $\mathrm{r}^{2}=0.692$, $\mathrm{p}=0.040$, respectively). However, the detected geographic and climatic dependences should be treated with caution because of the small number of tested populations of $Z$. carpinifolia.

\section{Differences between populations}

The average values of the characters representing the same type of shoot were generally similar but to some degree were specific for every population (Table 3). The differences between populations when comparing the leaves representing the same type of shoots (L or S) were tested using Tukey's HSD test. The highest number of characters of the leaves from L-type shoots differed in population BAB (Babaneuri in eastern Georgia) from the others, representing Anatolia in Turkey and Colchis in western Georgia (TRA, VAN, ANR) and Talysh in south-eastern Azerbaijan (GUN, XAN, and PAR). Interestingly, the Anatolian populations did not differ at all from any other population with respect of the leaf characters from L-type shoots (Table 4). Populations VAN and $B A B$ differed at the highest level from the others with respect to the characters of the leaves from the S-type shoots. The lowest numbers of differences between populations represented by fructifying shoots were found between population PAR and the others and between TRA and the others (Table 4). All of the particular characteristics of the leaves from L- and/ or from S-type shoots differentiated at statistically significant levels at least between two compared populations.

The multivariate analyses (PCA, discrimination, and agglomeration) indicated the most prominent separation of $\mathrm{BAB}$ compared to the other populations (Fig. 3A, B and C). In addition, the Talysh populations (XAN, GUN, and PAR) revealed differences from the Colchis-Anatolian populations (TRA, VAN, and ANR). These differences are more visible for the set of leaves from S-type shoots than from L-type shoots (Fig. 3A and B). The greatest difference in $\mathrm{BAB}$ was detected also in agglomeration on the shortest Euclidean distances, but only on the leaves from S-type shoots, while the differentiation of the Euclidean distances between populations for the leaves from L-type shoots did not show geographic characters (Fig. 3C). A similar dependence was also found using Mahalanobis distances between populations (data not shown).

\section{Taxonomic position of Zelkova hyrcana and Z. carpinifolia subsp. yomraensis}

Zelkova hyrcana individuals were very similar to those that were sampled as $Z$. carpinifolia subsp. carpinifolia with respect to both types of leaves. In addition, individuals of $Z$. carpinifolia subsp. yomraensis did not reveal any differences from the typical subsp. of $Z$. carpinifolia (Fig. 3A and B). Similar results for both of the discussed taxa were found using agglomerations of the Euclidean (Fig. 3C) and Mahalanobis distances for leaves from L- and S-type shoots (data not shown). Thus, we did not detect differences in the shape of leaves, indicating that the $Z$. hyrcana and/ or $Z$. carpinifolia subsp. yomraensis be distinguished as separate taxa. The level of differences that were found between these two taxa and other populations was similar to the differences among populations of $Z$. carpinifolia subsp. carpinifolia itself. The number of significant differences between $Z$. hyrcana and other populations and Z. carpinifolia subsp. yomraensis and other populations did not cross the numbers of characters differentiating a statistically significant level among the populations of $Z$. carpinifolia (Table 4). 


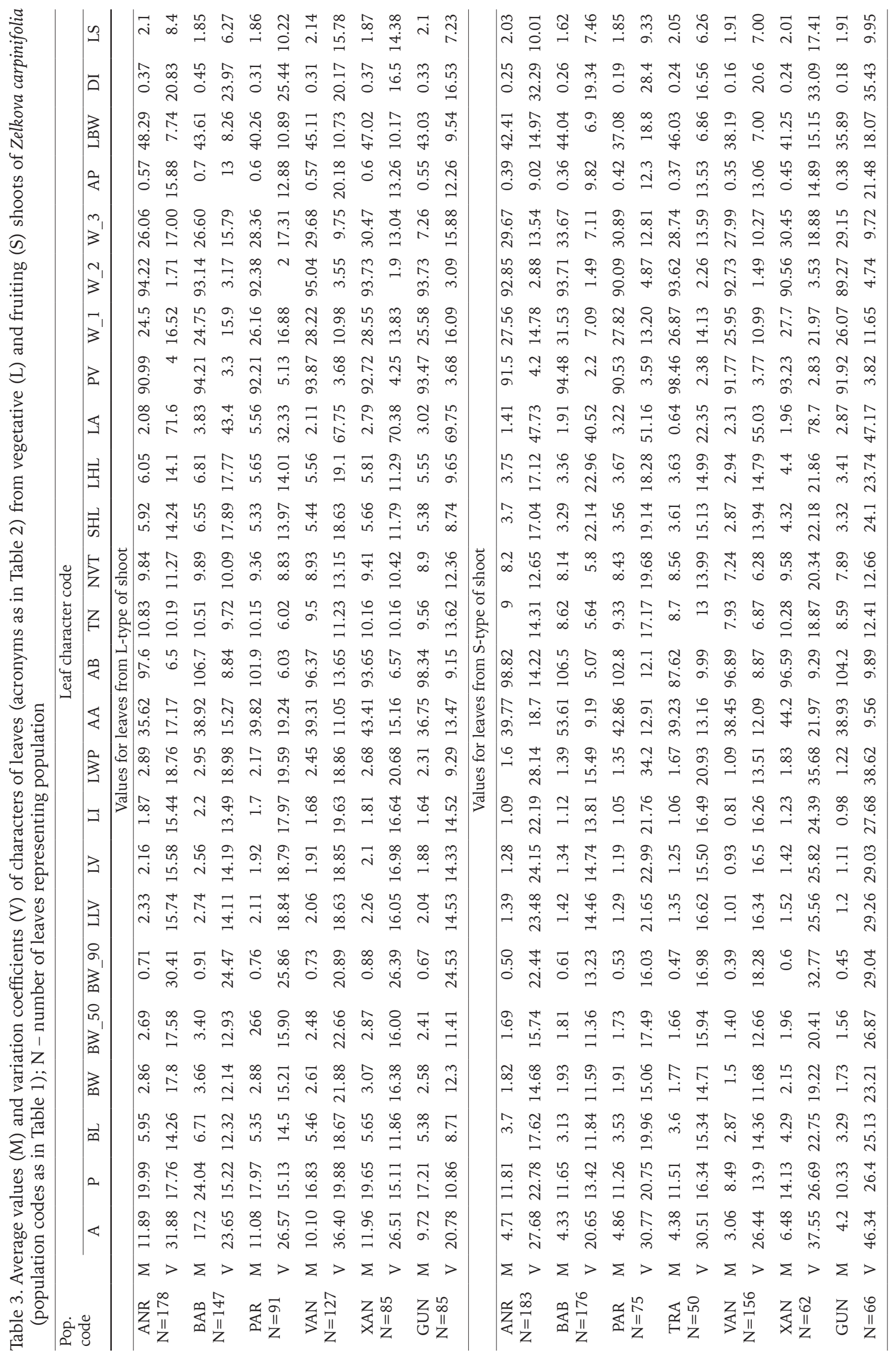


Table 4. Result of the Tukey's HSD T-test $(\mathrm{p} \leq \mathbf{0 . 0 1}$ and $p \leq 0.05)$ between populations (codes as in Table 1 ) on the Zelkova carpinifolia leaf characters (codes as in Table 2) from the vegetative (L) and fructifying (S) shoots

\begin{tabular}{|c|c|c|c|c|c|c|}
\hline $\mathrm{L}$ & TRA & VAN & ANR & $\mathrm{BAB}$ & GUN & XAN \\
\hline \multicolumn{7}{|l|}{ VAN } \\
\hline ANR & & $\mathrm{TN}$ & & & & \\
\hline $\mathrm{BAB}$ & & $\begin{array}{l}\text { A, P, BL, BW, } \\
\text { LLV, LV, LI, LS, } \\
\text { LHL, AP, DI, } \\
\text { SHL, AB }\end{array}$ & $\begin{array}{c}\text { A, P, BW, AP, } \\
B W \_90, L L V, L V, \\
L I, L A, L S, A B\end{array}$ & & & \\
\hline GUN & & & & $\begin{array}{l}\text { A, P, PL, BW, } \\
\text { LLV, LV, LI, LWP, } \\
\text { LHL, AP, DI }\end{array}$ & & \\
\hline XAN & & $A A$ & $\mathrm{LV}, A, P, L I, A B$ & & & \\
\hline PAR & & LA & LA, LBW, $L W P$ & $\begin{array}{l}\text { A, P, BL, BW, } \\
\text { LLV, LV, LI, } \\
\text { LWP, DI, SHL }\end{array}$ & $L A$ & LA, LBW \\
\hline$S$ & TRA & VAN & ANR & $\mathrm{BAB}$ & GUN & XAN \\
\hline VAN & PV & & & & & \\
\hline ANR & & $\begin{array}{c}\text { P, BL, LLV, LV, } \\
\text { LI, LWP, DI, } A \text {, } \\
B W, S H L, L H L\end{array}$ & & & & \\
\hline BAB & AA, LS, $A B$ & $\begin{array}{l}\text { P, BW, BW_90, } \\
\text { LLV, LV, LI, AA, } \\
\text { LS, DI, W_1, } \\
\text { W_3 } L B W\end{array}$ & $\begin{array}{c}\text { AA, LS, } W_{-} 1, \\
W_{-} 3\end{array}$ & & & \\
\hline GUN & LA, LBW, PV & & & $\begin{array}{c}\text { AA, } B W-90, \\
W_{-} 1, L B W, L S, \\
W_{-} 2\end{array}$ & & \\
\hline XAN & $P V$ & $\begin{array}{c}\text { A, P, BL, BW, } \\
\text { BW_90, LLV, LV, } \\
\text { LI, LWP, TN, } \\
\text { SHL, NVT, LHL, } \\
\text { AP, DI }\end{array}$ & & $\begin{array}{c}\text { BL, AA, W_1, } \\
\text { W_3, LS, } A, A A \text {, } \\
T N, S H L, L B W, \\
\text { LHL, } A P\end{array}$ & $\begin{array}{c}\mathrm{P}, A, B L, B W, \\
L W P, T N, S H L \\
\quad N V T, L H L\end{array}$ & \\
\hline PAR & LA, PV, LBW & $B W, A P$ & LA & & & \\
\hline
\end{tabular}

\section{Geographic pattern of variation}

The tested populations did not show a clear geographic pattern of multivariate differentiation on the leaves from L- or S-type shoots; however, some regularities can be observed: (1) the northernmost and geographically isolated BAB population is characterized by a high level of differences with respect to the leaves from the L- and S- shoots (Fig. 3A, $\mathrm{B}$ and C); (2) the Colchis populations of ANR and VAN are isolated from the Talysh populations of GUN, XAN and PAR with respect to the leaves from both types of shoots, and (3) the Anatolian TRA is similar to that of the Colchis populations (Fig. 3A, $\mathrm{B}$ and $\mathrm{C})$.

The Mantel test that was conducted using the Euclidean distances compared to geographic distances did not show dependence with $r=0.062, p=0.788$ and $r=0.086, p=0.675$ for L-type and S-type leaves, respectively. The square of Mahalanobis distances, however, detected weak but significant correlations with the geographic distances among populations, at $r=0.504, p=0.032$ and $r=0.358, p=0.043$ for L-type and S-type leaves, respectively.
The barriers that were constructed on Euclidean and Mahalanobis distances using Barrier software confirmed the validity of the differences between population $\mathrm{BAB}$ and the others in data from both types of leaves (L and S) using Euclidean and Mahalanobis distances (Fig. 1A and B). In addition, differences in the population TRA to other Colchis-Caucasian and GUN to others from Talysh have been detected.

\section{Discussion}

\section{Leaf characteristics}

The leaves of $Z$. carpinifolia have not been verified biometrically until now using such a high number of characters. Our data, which resulted from the measurement of more than 700 leaves from two types of shoots, provide the most adequate data but only for the plant material from the middle part of the shoot. However, the results presented here are generally similar to previously reported data (Table 5 ). We found the average values of BL with the range of data that have been reported in the floras, independent of 
Table 5. Average values and range of variation of BL, BW and NVT of Zelkova carpinifolia s.str., Z. hyrcana and Z. carpinifolia subsp. yomraensis, received in the study (bolded) compared to literature data

\begin{tabular}{|c|c|c|c|}
\hline Character & Value & Remarks & Source of data \\
\hline \multicolumn{4}{|c|}{ Zelkova carpinifolia } \\
\hline \multirow[t]{8}{*}{$\mathrm{BL}$} & $4-6 \mathrm{~cm}$ & & Grossgeim 1930 \\
\hline & $4-8 \mathrm{~cm}$ & & Lozina-Lozinskaya 1951 \\
\hline & $(1.5-) 2-3.5(4.6) \mathrm{cm}$ & & Prilipko 1961 \\
\hline & to $10-12 \mathrm{~cm}$ & on SS type of shoot & Prilipko 1961 \\
\hline & $(1.5-) 2-8(-9) \mathrm{cm}$ & & Browicz and Zieliński 1982b \\
\hline & up to $8(-10) \mathrm{cm}$ & & Zieliński 1979 \\
\hline & $5.83(2.54-10.62) \mathrm{cm}$ & L type of shoot & Own data \\
\hline & $3.43(1.13-6.26) \mathrm{cm}$ & S type of shoot & Own data \\
\hline \multirow[t]{5}{*}{ BW } & $2-4 \mathrm{~cm}$ & & Lozina-Lozinskaya 1951 \\
\hline & $(1-) 1.5-4(-4.5) \mathrm{cm}$ & & Browicz and Zieliński 1982b \\
\hline & up to $4(-4.5) \mathrm{cm}$ & & Zieliński 1979 \\
\hline & $2.97(1.44-5.53) \mathrm{cm}$ & L type of shoot & Own data \\
\hline & $1.82(0.59-2.92) \mathrm{cm}$ & S type of shoot & Own data \\
\hline \multirow[t]{7}{*}{ NVT } & $4-8$ & & Lozina-Lozinskaya 1951 \\
\hline & $(4-) 6-7(-9)$ & & Prilipko 1961 \\
\hline & $6-10(-12)$ & & Browicz and Zieliński 1982b \\
\hline & $(3-)$ 6-12 & & Wang et al. 2001 \\
\hline & up to 12 & & Denk and Grimm 2005 \\
\hline & $9.45(5-15)$ & $\mathrm{L}$ type of shoot & Own data \\
\hline & $8.19(4-15)$ & S type of shoot & Own data \\
\hline \multicolumn{4}{|c|}{ Zelkova hyrcana } \\
\hline \multirow[t]{2}{*}{$\mathrm{BL}$} & $4-6(-7.5) \mathrm{cm}$ & & Prilipko 1961 \\
\hline & to $12 \mathrm{~cm}$ & on SS type of shoot & Prilipko 1961 \\
\hline NVT & $(6-) 7-9(-12)$ & & Prilipko 1961 \\
\hline \multicolumn{4}{|c|}{ Zelkova carpinifolia subsp. yomraensis } \\
\hline BL & $2-5(-6) \mathrm{cm}$ & & Anşin and Gerçek 1991 \\
\hline BW & $(0.8-) 1.5-2(-2.5) \mathrm{cm}$ & & Anşin and Gerçek 1991 \\
\hline NVT & $6-8(-9)$ & & Anşin and Gerçek 1991 \\
\hline
\end{tabular}

the origin from the $\mathrm{L}$ versus $\mathrm{S}$ shoot types. The leaves from the L shoots have an average BL value that falls near the mid-distance between reported data, while that from the $S$ shoots was closer to a lower distance. A similar situation can be observed in the case of BW. We found the lowest values of minima and highest values of maxima BL and BW, albeit that we analyzed leaves that were sampled from the central parts the shoots. This result can be interpreted that in the central parts of shoots of $Z$. carpinifolia, the leaves are generally the largest, also confirming the pertinence of sampling for biometrical studies, as previously suggested (e.g., Wójcicki 1997; Kremer et al. 2002; Krauze-Michalska and Boratyńska 2013).

The average number of lateral leaf veins was generally higher or close to the upper range limits that were reported by previous authors. We also found the highest ranges of variation of this character when compared to reported data (Table 5). The higher values of this character can result from the more-detailed counting by one investigator in our dataset.

We described the leaves using a broad set of characters, most of which were not been previously used. In this respect, we provide for the first time data on
A, P, BL, BW, LLV, LV, LI, LWP, AA, AB, TN, NVT, DI and several other proportions. We expect that this set of data will be useful in the identification of fossil types (compare for example Hably and Kvaček 1998; Kvaček 1998; Denk and Grimm 2005; Kvavadze and Connor 2005).

\section{Differences between the leaves from $\mathrm{L}$ and $S$ shoots}

The leaves from the L-type shoot of $Z$. carpinifolia were had larger dimensions (e.g., Lozina-Lozinskaya 1951; Prilipko 1961; Browicz and Zieliński 1982b). The differences in characters other than BL and BW, however, have not been evaluated until now. We found that all the dimensional characters, which are correlated with each other, have significantly higher average values in leaves from L-type shoots compared to data concerning the leaves from $\mathrm{S}$ shoots (Table 2). Interestingly, the first three, the most correlated characters (A, P, and BL) have a higher level of variation in the $S$ shoot leaves set (Table 2). The angle of leaf apex (AA), as only one character with a significantly higher average value for the $S$ shoot 
leaves, also has higher level of variation than that observed in the set of $\mathrm{L}$ shoot leaves.

The differences between the leaves from $\mathrm{L}$ and $\mathrm{S}$ shoots in Z. carpinifolia are comparable to the differences between the leaves from vegetative long shoots versus fertile short shoots of other tree species with elliptic and/or ovate leaves (e.g., Wójcicki 1997, but see also Jentys-Szaferowa 1970 and Staszkiewicz 1997). Interestingly, a broad apex angle was observed on the leaves from fructifying short shoots of Alnus viridis (Chaix) DC. (Wójcicki 1997), Corylus avellana L. (Białobrzeska 1970a) and Carpinus betulus L. (Białobrzeska 1970b). The fruiting short shoot leaves of the mentioned species had a generally broader apex angle than did the leaves from vegetative long shoots. However, inverse proportions of this character were detected in leaves of Tilia cordata Mill. (Staszkiewicz 1970). In addition, the characters of leaves from long versus short shoots were different, with generally lower average values of the latter (Jentys-Szaferowa 1970; Staszkiewicz 1997 and literature cited herein). We found similar differences between the verified sets of leaves of type $L$ and $S$ shoots in every studied population of $Z$. carpinifolia (Table 3; Fig. 3A, B and C).

\section{Position and climate influence on the leaf characteristics}

The most of tested leaf characters did not reveal dependence on geographic latitude, longitude or altitude nor on the basic climatic data (AMT, APR). We found such dependences only for two characters of S-type leaves, namely W_ 2 in latitude and negatively in longitude and $A B$ on AMT and APR. It is surprising that the different climatic data of particular population (Table 1) did not cause a higher number of differences in the phenotypic characters of the leaves. It is noteworthy the similar tendency of variation in $A B$ of Alnus incana (L.) Moench leaves (Krauze-Michalska and Boratyńska 2013).

A relatively higher number of dependences between leaf characters and bioclimatic factors has been detected for Salix herbacea (Marcysiak 2012c). The differences between $Z$. carpinifolia and S. herbacea may result from the ecological conditions of their occurrence. Salix herbacea is an arctic-alpine plant that is grown in the harsh climatic conditions of tundra or the alpine vegetation belt in the mountains, while $Z$. carpinifolia is a component of humid broad-leaved woods of low areas, up to altitudes of $1500 \mathrm{~m}$ in the Colchis and/or Hyrcanian mountains (regions after Browicz and Zieliński 1982b; Takhtadzhian 1986). In addition, the $A$. incana reaction to climatic data was rather low, which was explained by its occurrence on the river banks in humid forest vegetation (Krauze-Michalska and Boratyńska 2013).

\section{Multivariate differences between populations}

The results of the multivariate analyses indicated geographic isolation between 3 groups of the analyzed populations, namely from Colchis and Anatolia (TRA, VAN, ANR), from Transcaucasia (BAB) and from the Talysh (GUN, XAN and PAR) that was the most prominent when using leaves from the S-type shoots. The L-type shoot leaves revealed mostly different characters of Transcaucasian population (BAB), which may indicate an independent pattern of variation in the leaves from S- and L-type shoots in every population of $Z$. carpinifolia; however, both datasets correlate at very high level $(r=0.995)$. The leaves from the short shoots were more frequently used in the analyses of variation of several woody species as generally less variable (e.g., Jentys-Szaferowa 1970; Staszkiewicz 1997).

The differences between populations that were found during our study resembled the haplotypic differentiation of $Z$. carpinifolia as detected using two chloroplast markers (Christe et al. 2014). We have only 7 populations of 15 examined genetically, but biometric analyses revealed a similar pattern of differentiation when using the leaves from S-type shoots. Genetic differences are considered to be ancient, resulting from spatial isolation in particular regions with the subsequent extinction of populations of intermediate character between regions (Christe et al. 2014). The reduction of the species range and the extinction of several populations can result from a reduction of Paratethys during late Miocene and Pliocene (Popov et al. 2006) and the climate changes that are connected with that process. The lack of direct dependency on most of the tested morphological characters on the climatic factors of particular populations (see above) can indicate the genetic condition of leaf morphology. Similar patterns of genetic and morphological differentiation of populations were found in several other species (e.g., compare Terrab et al. 2008 with Boratyński et al. 2013; Terrab et al. 2007 with Sękiewicz et al. 2013, see also Boratyński et al. 2014).

\section{Taxonomic position of Zelkova hyrcana and Z. carpinifolia subsp. yomraensis}

We did not detect significant differences in the leaf characters between supposed $Z$. hyrcana and/or $Z$. carpinifolia subsp. yomraensis (population GUN and TRA, respectively) when compared to $Z$. carpinifolia s. str. (Table 1). The GUN population appeared similar to the two other populations from the Talysh, while TRA to the two populations from the Colchis (Fig. $3 \mathrm{~A}, \mathrm{~B}$ and $\mathrm{C})$. However, the barriers that were detected using Barrier 2.2 separate the TRA population 
from other Colchis populations (Fig. 1) and GUN from other Talysh populations. These differences, which were revealed using Euclidean and Mahalanobis' distances, have not been detected in multivariate analyses or in analyses of differences using particular characters (Table 4).

The results of genetic differentiation analyses also did not find significant differences between $Z$. hyrcana and $Z$. carpinifolia subsp. yomraensis when compared to typical subspecies of $Z$. carpinifolia (Christe et al. 2014). Thus, neither genetic nor biometric studies on the leaf characteristics confirmed the separate taxonomic status of either $Z$. hyrcana or $Z$. carpinifolia subsp. yomraensis. Our results support the inclusion of these species into the synonyms of $Z$. carpinifolia, as has been noted in several taxonomic studies (Czerepanov 1957; Safarov 1967; Browicz and Zieliński 1982a,b; Zieliński 1979; Zieliński and Güner 2000). The values of the characters, which are typical for $Z$. hyrcana, namely leaves from vegetative shoots that are $2-3.5 \mathrm{~cm}$ long with 6-7 veins (Prilipko 1961), appeared in GUN as significantly higher and similar to the average values of these characters of leaves from L-type shoots in other compared populations (Table 3). We must state that the population GUN represents typical Z. carpinifolia.

Zelkova carpinifolia subsp. yomraensis was described from vicinities of Trabzon as a shrub with leaves that were (1-)2-8(-9) cm long and (1-)1.5-4(-4.5) cm wide, with 6-10(-12) lateral veins (Anșin and Gerçek 1991). The material that was collected from 7 specimens in the same region of Anatolia and that was used in the present study did not reveal differences when compare to other populations. We did not discard the L-type leaves from the TRA populations, and we did not study the anatomical characteristics of the wood; therefore, we can conclude that the leaf characters did not confirmed the separate systematic status of this taxon. The leaf characters of the type of $Z$. carpinifolia subsp. yomraensis were found as representing the specimen as deformed by grazing (Zieliński and Güner 2000). In the genetic study, the TRA population did not reveal drastic differences from the other populations that were sampled in Colchis (Christe et al. 2014).

\section{Conclusions}

Our study shows a very high level of differentiation between the leaves from the L- and S-type shoots of Zelkova carpinifolia. The majority of the leaf characters did not reveal dependence on geographic latitude, longitude or altitude nor on the basic climatic data. The different climatic conditions of a particular population did not cause a greater number of differences in the phenotypic characters of the leaves. The results of multivariate analyses of S-type shoots revealed some geographic pattern of variation between the three groups of analyzed populations, namely from (1) Colchis, from the (2) eastern Caucasus (Babaneuri) and from the (3) Talysh region in south-eastern Azerbaijan. Thus, our biometric analyses revealed a similar pattern as that of the haplotypic differentiation of $Z$. carpinifolia detected as described in the literature using chloroplast markers. Additionally, we did not detect significant differences in the leaf characters between the supposed $Z$. hyrcana and/ or Z $Z$. carpinifolia subsp. yomraensis when compared to $Z$. carpinifolia, thus not confirming their separate taxonomic status. Moreover, our data provide precise comparative material for future palaeobotanical studies.

\section{Acknowledgements}

This work was supported by the BGCI (Botanic Gardens Conservation International, United Kingdom) and by the Institute of Dendrology. We are grateful to I. Kaya, M. Khutsishvili, V. Farzalijev, D. Frey, R. Keller and E. Gerber for the collection of the material and M. Łuczak for technical assistance and the preparation of the herbarium. Special thanks to V. Alizade, E. Alirzayeva and J. Gratzfeld for the coordination of international collaborations and permits.

\section{References}

Aliyev J.A. 1995. Azerbaijan: Country report to the FAO International Technical Conference on plant genetic resources. Baku.

Anşin R., Gerçek Z. 1991. Türkiye Florası İçin Yeni Bir Zelkova Taksonu. Zelkova carpinifolia (Pall.) C. Koch ssp. yomraensis Anşin \& Gerçek, ssp. nova. Doğa. Turkish Journal of Agriculture and Forestry 15: 564-575 (In Turkish).

Białobrzeska M. 1970a. Leszczyna (Coryllus avellana L.). In: Zmienność liści i owoców drzew i krzewów w zespołach leśnych Białowieskiego Parku Narodowego [Variability of the leaves and fruits of trees and shrubs in forest associations of the Bialowieża National Park]. Jentys-Szefrowa J. (ed.). Monographiae Botanicae 32: 66-85 (In Polish).

Białobrzeska M. 1970b. Grab zwyczajny (Carpinus betulus L.). In: Zmienność liści i owoców drzew i krzewów w zespołach leśnych Białowieskiego Parku Narodowego [Variability of the leaves and fruits of trees and shrubs in forest associations of the Bialowieża National Park]. Jentys-Szefrowa J. (ed.). Monographiae Botanicae 32: 86-100 (In Polish). 
Boratyński A., Browicz K., Zieliński J. 1987. Woody flora of Chios. Arboretum Kórnickie 32: 37-92.

Boratyński A., Jasińska A.K., Marcysiak K., Mazur M., Romo A., Boratyńska K., Sobierajska K., Iszkuło G. 2013. Morphological differentiation supports the genetic pattern of the geographic structure of Juniperus thurifera (Cupressaceae). Plant Systematics and Evolution 299: 773-784.

Boratyński A., Wachowiak W., Dering M., Boratyńska K., Sękiewicz K., Sobierajska K.I., Jasińska A.K., Klimko M., Montserrat J.M., Romo A., Ok T., Didukh Ya. 2014. The biogeography and genetic relationships of Juniperus oxycedrus L. and related taxa from the Mediterranean and Macaronesian regions. Botanical Journal of the Linnean Society 174: 637-653.

Browicz K., Zieliński J. 1982a. Zelkova Spach. In: Flora of Turkey and the East Aegean Islands. Davis P.H. (red.). University Press, Edinburgh pp. 648649.

Browicz K., Zieliński J. 1982b. Chorology of trees and shrubs in South-West Asia and adjacent regions. Institute of Dendrology, Polish Scientific Publishers, Warszawa-Poznań.

Burnham R.J. 1986. Foliar morphological analysis of the Ulmoideae (Ulmaceae) from the early Tertiary of western North America. Palaeontographica Abteilung B 201: 135-167.

Christe C., Kozlowski G., Frey D., Bétrisey S., Maharramova E., Garfi G., Pirintsos S., Naciri Y. 2014. Footprints of past intensive diversification and structuring in the genus Zelkova (Ulmaceae) in south-western Eurasia. Journal of Biogeography 41: 1081-1093.

Czerepanov S.K. 1957. Revision specierum generum Zelkova Spach et Hemiptelea Planchon. Botaniceskie Materialy Gerbarija Botaniceskogo Instituta imieni V.L. Komarova Akademii Nauk SSSR 18: $58-72$.

Denk T., Grimm G. W. 2005. Phylogeny and biogeography of Zelkova (Ulmaceae sensu stricto) as inferred from leaf morphology, ITS sequence data and the fossil record. Botanical Journal of the Linnean Society 147: 129-157.

Güner A., Zielinski J. 1998. Zelkova carpinifolia. IUCN Red List of Threatened Species. Version 2010.4. International Union for Conservation of Nature and Natural Resources, Gland, Switzerland. Available at: http://www.iucnredlist.org/ details/31303/0 (accessed April 2014).

Hably L. 1997. Early Pliocene volcanic environment, flora and fauna from Transdanubia, West Hungary. Studia Naturalia 10: 5-153.

Hably L., Kvaček Z. 1998. Pliocene mesophytic forests surrounding crater lakes in western Hungary. Review of Palaeobotany and Palynology 101: 257-269.
Jentys-Szaferowa J. 1970 (ed.). Zmienność liści i owoców drzew i krzewów w zespołach leśnych Białowieskiego Parku Narodowego [Variability of the leaves and fruits of trees and shrubs in forest associations of the Białowieża National Park]. Monographiae Botanicae 32: 5-238 (In Polish).

Kovačić S., Nikolić T. 2005. Relations between Betula pendula Roth. (Betulaceae) leaf morphology and environmental factors in five regions of Croatia. Acta Biologica Cracoviensia, Series Botanica 47: 7-13.

Kozlowski G., Gibbs D., Huan F., Frey D., Gratzfeld J. 2012. Conservation of threatened relict trees through living ex situ collections: lessons from the global survey of the genus Zelkova (Ulmaceae). Biodiversity and Conservation 21: 671-685.

Kozlowski G., Gratzfeld J. 2013. Zelkova - an ancient tree. Global status and conservation action. Natural History Museum Fribourg, Fribourg.

Krauze-Michalska E., Boratyńska K. 2013. European geography of Alnus incana leaf variation. Plant Biosystems 147: 601-610.

Kremer A., Dupouey J.L., Deans J.D., Cottrell J., Csaikl U., Finkeldey R., Espinel S., Jensen J., Kleinschmit J., Van Dam B., Ducousso A., Forrest I., Lopez de Heredia U., Lowe A.J., Tutkova M., Munro R.C., Steinhoff S., Badeau V. 2002. Leaf morphological differentiation between Quercus robur and Quercus petraea in stable across western European mixed oak stands. Annals of Forest Sciences 59: 777-787.

Kvaček Z. 1998. Bílina: a window on Early Miocene marshland environments. Review of Palaeobotany and Palynology 101: 111-123.

Kvavadze E.V., Connor S.E. 2005. Zelkova carpinifolia (Pallas) K. Koch in Holocene sediments of Georgia - an indicator of climatic optima. Review of Palaeobotany and Palynology 133: 69-89.

Lozina-Lozinskaya A.S. 1951. Ulmaceae Mirb. In: Derevya i kustarniki SSSR. 2. Sokolov S.Ya. (ed.). Moskva-Leningrad, pp. 493-523 (In Russian).

Mai D.H. 1995. Tertiäre vegetationsgeschichte Europas. Gustav Fischer Verlag, Jena.

Manchester S. 1989. Systematics and fossil history of the Ulmaceae. In: Evolution, Systematics and Fossil History of the Hamamelidae. Vol. 2. Crane P.R., Blackmore S. (eds.). Clarendon Press, Oxford, pp. 221-251.

Manni F., Guerard E., Heyer E. 2004. Geographic patterns of (genetic, morphologic, linguistic) variation: how barriers can be detected by using Monmonier's algorithm. Human Biology 76: 173-190.

Mantel N. 1967. The detection of disease clustering and a generalized regression approach. Cancer Research 27: 209-220.

Marcysiak K. 2012a. Calculated characters of leaves are independent on environmental conditions in 
Salix herbacea (Salicaceae) and Betula nana (Betulaceae). Acta Societatis Botanicorum Poloniae 81: 153-158.

Marcysiak K. 2012b. Diversity of Salix reticulata L. (Salicaceae) leaf traits in Europe and its relation to geographical position. Plant Biosystems 146: 101-111.

Marcysiak K. 2012c. Variation of leaf shape of Salix herbacea in Europe. Plant Systematics and Evolution 298: 1597-1607.

Mejnartowicz L. 1972. Badania zmienności populacji Alnus glutinosa (L.) Gaertn. w Polsce. Arboretum Kórnickie 17: 43-120 (In Polish).

Milne R.I., Abbott R.J. 2002. The origin and evolution of Tertiary relict floras. Advances in Botanical Research 38: 281-314.

Popov S.V., Shcherba I.G., Ilyina L.B., Nevesskaya L.A., Paramonova N.P., Khondkarian S.O., Magyar I. 2006. Late Miocene to Pliocene palaeogeography of the Paratethys and its relation to the Mediterranean. Palaeogeography, Palaeoclimatology, Palaeoecology 238: 91-106.

Prilipko L.I. 1961. Zelkova Spach. In: Dendroflora Kavkaza, 2. Gulisashvili V.Z. (ed.). Institut Lesa Gruzinskoy AN, Tbilisi, pp. 308-318 (In Russian).

Safarov I.S. 1967. Some results of the investigations of the intraspecific taxonomy in the relict forest phytocoenosis of Talysh Mts. Botanicheskiy Zhurnal 52: 772-781 (In Russian).

Sękiewicz K., Sękiewicz M., Jasińska A.K., Boratyńska K., Iszkuło G., Romo A., Boratyński A. 2013. Morphological diversity and structure of West Mediterranean Abies species. Plant Biosystems 147: 125-134.

Sokal R.R., Rohlf F.J. 2003. Biometry. The principles and Practice of Statistics in Biological Research. Third Edition. W. H. Freeman and Co., New York.

Stanisz A. 2007a. Przystępny kurs statystyki z zastosowaniem STATISTICA PL na przykładach $z$ medycyny. Tom 2. Modele liniowe i nieliniowe. StatSoft, Kraków (In Polish).

Stanisz A. 2007b. Przystępny kurs statystyki z zastosowaniem STATISTICA PL na przykładach $z$ medycyny. Tom 3. Analizy wielowymiarowe. StatSoft, Kraków (In Polish).

Staszkiewicz J. 1970. Lipa drobnolistna (Tilia cordata Mill.). In: Zmienność liści i owoców drzew i krzewów w zespołach leśnych Białowieskiego Parku Narodowego [Variability of the leaves and fruits of trees and shrubs in forest associations of the Białowieża National Park]. Jentys-Szefrowa J. (ed.). Monographiae Botanicae 32: 159-171 (In Polish).

Staszkiewicz J. 1997 (ed.). Zmienność wybranych gatunków drzew i krzewów [Variability of selected shrub and tree species]. Fragmenta Floristica et Geobotanica, Ser. Polonica, suppl. 2 (In Polish).

Takhtadzhian A.L. 1986. Floristic regions of the world. University of California Press, Berkeley.

Terrab A., Schoenswetter P., Talavera S., Vela E., Stuessy T.F. 2008. Range-wide phylogeography of Juniperus thurifera L., a presumptive keystone species of western Mediterranean vegetation during cold stages of the Pleistocene. Molecular Phylogenetics and Evolution 48: 94-102.

Terrab A., Talavera S., Arista M., Paun O., Stuessy T.F., Tremetsberger K. 2007. Genetic diversity and geographic structure at chloroplast microsatellites (cpSSRs) in endangered West Mediterranean firs (Abies spp., Pinaceae). Taxon 56: 409-416.

Uotila P. 2011. Ulmaceae. - In: Euro+Med Plantbase - the information resource for Euro-Mediterranean plant diversity, http://ww2.bgbm.org/ EuroPlusMed/

Wang Y.-F., Ferguson D.K., Zetter R., Denk T., Garfi G. 2001. Leaf architecture and epidermal characters in Zelkova, Ulmaceae. Botanical Journal of the Linnean Society 136: 255-265.

Wójcicki J.J. 1997. Zmienność liści olszy zielonej Alnus viridis (Betulaceae) [The variability of leaves of Alnus viridis (Betulaceae)]. Fragmenta Floristica et Geobotanica, ser. Polonica Suppl. 2: 5-13 (In Polish).

Xu F., Guo W., Xu W., Wei Y., Wang R. 2009. Leaf morphology correlates with water and light availability: What consequences for simple and compound leaves? Progress Natural Sciences 19: 1789-1798.

Zar J.H. 1999. Biostatistical Analysis. Prentice Hall, New Jersey.

Zieliński J. 1979. Ulmaceae. In: Flora Iranica 142. Rechinger K.H. (ed.). Akademische Druck und Vermagsanstalt, Graz.

Zieliński J., Güner A. 2000. Zelkova Spach. In: Flora of Turkey and the East Aegean Islands. Güner A., Özhatay N., Ekim T., Başer K.H.C. (eds.). Edinburgh University Press, Edinburgh. 